\title{
Bicycle Industry in India and its Challenges - A Case Study
}

\author{
Puneeth B. R. ${ }^{1,2}$ \& Nethravathi P. S. ${ }^{3}$ \\ ${ }^{1}$ Research Scholar, College of Computer Science and Information Science, Srinivas \\ University, Mangaluru, India \\ ${ }^{2}$ Assistant Professor, Department of M.C.A, NMAMIT, Nitte, Karkala, India \\ OrcidID: 0000-0003-1985-0411; E-mail: puneethbr9@gmail.com \\ ${ }^{3}$ Professor, College of Computer Science and Information Science, Srinivas University, \\ Mangaluru, India \\ OrcidID: 0000-0001-5447-8673; E-mail: nethrakumar590@ gmail.com
}

Area of the Paper: Management.

Type of the Paper: Research Case Study.

Type of Review: Peer Reviewed as per $|\mathrm{C}| \mathrm{O}|\mathrm{P}| \mathrm{E} \mid$ guidance.

Indexed In: OpenAIRE.

DOI: http://doi.org/10.5281/zenodo.5205299

Google Scholar Citation: IJCSBE

\section{How to Cite this Paper:}

Puneeth, B. R. \& Nethravathi, P. S. (2021). Bicycle Industry in India and its Challenges A Case Study. International Journal of Case Studies in Business, IT, and Education (IJCSBE), 5(2), 62-74. DOI: http://doi.org/10.5281/zenodo.5205299.

International Journal of Case Studies in Business, IT and Education (IJCSBE)

A Refereed International Journal of Srinivas University, India.

Crossref DOI : https://doi.org/10.47992/IJCSBE.2581.6942.0120

(C) With Authors.

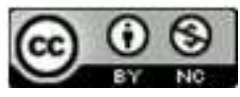

This work is licensed under a Creative Commons Attribution Non-Commercial 4.0 International License subject to proper citation to the publication source of the work.

Disclaimer: The scholarly papers as reviewed and published by the Srinivas Publications (S.P.), India are the views and opinions of their respective authors and are not the views or opinions of the S. P. The S. P. disclaims of any harm or loss caused due to the published content to any party. 


\title{
Bicycle Industry in India and its Challenges - A Case Study
}

\author{
Puneeth B. R. ${ }^{1,2}$ \& Nethravathi P. S. ${ }^{3}$ \\ ${ }^{1}$ Research Scholar, College of Computer Science and Information Science, Srinivas \\ University, Mangaluru, India \\ ${ }^{2}$ Assistant Professor, Department of M.C.A, NMAMIT, Nitte, Karkala, India \\ OrcidID: 0000-0003-1985-0411; E-mail: puneethbr9@ gmail.com \\ ${ }^{3}$ Professor, College of Computer Science and Information Science, Srinivas University, \\ Mangaluru, India \\ OrcidID: 0000-0001-5447-8673; E-mail: nethrakumar590@ gmail.com
}

\begin{abstract}
Background/Purpose: Bicycles are a popular means of transportation in rural areas, especially among low-income populations, but they are also gaining popularity in metropolitan areas, especially among the fortunate and affluent. The Indian bicycle industry is dominated by roadsters, fancy, teenagers, and other types of bicycles such bicycles include mountain bikes, sports bikes, hybrid bikes, touring bikes, and other motorcycles. This article provides a comprehensive analysis of India's bicycle industry and examined it in depth.

Objective: To observe the growth and challenges of Bicycle Industries and review the contributing factors that helped this growth.

Design/Methodology/Approach: Analysis and presentation of information collected from various scholarly articles, web articles, and using SWOT framework.

Findings/Result: Based on the analysis of facts and figures and also by looking at the various scenarios of expansion of the Bicycle industry in India, it is seen that this industry has seen considerable growth and progress in various avenues such as the country's economy, the contribution of the international economy, research in bicycle area. Few recommendations are also suggested to take the concept further.
\end{abstract}

Originality/Value: This paper study provides a concise overview of the bicycle industry based on the different data gathered, as well as information on its existing state, needs, and potential for future improvement.

Paper type: A Research Case study paper on growth, challenges of the bicycle industry in India.

Keywords: Bicycle industry, urban area, livelihoods, labor's lockdown, COVID-19, Engineering exports, industry, economy

\section{INTRODUCTION :}

Bicycles have been a major vehicle for personal transport for decades. As technology has advanced, the bicycle trend in India has decreased among the middle and highly-earned, but the importance of this trend returns due to fitness and adventure biking priorities. Growing congestion, industrialization, and sustainability are pushing rising cycling demand in India. The state of Punjab was the largest producer of cycles, with almost 10.5 million units produced in 2017.

China's bike manufacturers are expected to enter Punjab by incorporating lightweight technologies and stimulating the industry. In addition, it has fueled the growth of India's bicycle industry, with digital shopping growing rapidly and a significant market share anticipated to accelerate and over the forecasted period. The 80 percent of the population who belong to the medium and low-income community and have an increased preference in physique shopping continues to prioritize sales across the period specialty off-line stores. The e-bike movement is gearing up for existing and future enthusiasts to rise [1].

By 2022, e-bikes may produce a 50\% stake in the overall bicycle market on a global basis. Brands like Atlas, Hero Cycles, Avon cycles deliver massive consumer presence, low to medium-priced bikes, 
which accounted for about 60\% of 2017's market share. Brands like Firefox and Decathlon's B'Twin penetrate the high price market. In the predicted period of 2017-2030 [2], Goldstein Market Intelligence analysts forecast that the Indian bicycle industry will rise in a CAGR of $8.6 \%$.

\section{RESEARCH RELATED WORK :}

Gupta, s. et al, (2020) concluded about how Indian manufacturers might be more quality sensitive when dealing with bicycles from other countries [3]. Aradhya Munjal (2020) tried to find and analyses the growth trajectories of Bicycle in a new business climate and sustainable development narratives in research. The article concludes that the Bicycle has not only contributed considerably to economic activity and progress in India but has also helped to the creation of jobs by employing ground-breaking business tactics, while remaining inclusive and ethical in its development route [4]. Sambit Kumar Beura's. et all, (2021) goal is to promote bicycle use in India while also improving human health and goal of this research is to add environmental healthiness factors into the evaluation of urban street performance [5]. Samyajit Basu. et all, (2013) from the user's perspective investigate the impact of several bicycle-friendly facilities in Indian urban areas. A poll was done in four major Indian cities to gather data on bicycle-friendly infrastructures based on popular opinion, with the facility to ride a bicycle on public transportation being the least desired option [6].

Table 1 lists the research scholar who published the area of bicycle, along with the study area, analysis, and research topic, as well as references.

Table 1: Related Research Work

\begin{tabular}{|c|c|c|c|}
\hline $\begin{array}{l}\text { SI. } \\
\text { No. }\end{array}$ & Area of Study & Focus & Reference \\
\hline 1 & Travel & A global history of Bicycle & $\begin{array}{l}\text { Glen Norcliffe, } \\
\text { (2016). [7] }\end{array}$ \\
\hline 2 & Health strategies & $\begin{array}{l}\text { The business-as-usual scenario is compared to } \\
\text { the bicycle superhighway (BSH) scenario. }\end{array}$ & $\begin{array}{l}\text { Amit Agarwal, } \\
(2021) .[8]\end{array}$ \\
\hline 3 & Electric bicycle & $\begin{array}{l}\text { Model of bicycle which is power assisted has } \\
\text { been designed }\end{array}$ & $\begin{array}{l}\text { Dhanyashree, G et } \\
\text { all. (2021). [9] }\end{array}$ \\
\hline 4 & New Technology & $\begin{array}{l}\text { Health analysis of the Bicycle rider using } \\
\text { different technology }\end{array}$ & $\begin{array}{l}\text { Nath, S. et all. } \\
\text { (2017). [10] }\end{array}$ \\
\hline 5 & Safety strategies & $\begin{array}{l}\text { The system detects falls while pedalling, } \\
\text { demonstrating the possibility of a bicycle } \\
\text { accident detection system. }\end{array}$ & $\begin{array}{l}\text { F. Tabei et all. } \\
\text { (2021). [11] }\end{array}$ \\
\hline 6 & $\begin{array}{l}\text { Economic } \\
\text { strategies }\end{array}$ & $\begin{array}{l}\text { The study concludes that inflation hike cannot } \\
\text { impact the bicycle exports positively or } \\
\text { negatively }\end{array}$ & $\begin{array}{l}\text { Valiachi, G. (2020). } \\
\text { [12] }\end{array}$ \\
\hline 7 & Innovations & $\begin{array}{l}\text { Innovation of bicycles in its design, utility, and } \\
\text { applications }\end{array}$ & $\begin{array}{l}\text { Baviskar, D et all. } \\
\text { (2021). [13] }\end{array}$ \\
\hline 8 & $\begin{array}{l}\text { COVID-19 } \\
\text { impact }\end{array}$ & $\begin{array}{l}\text { Study about the forced DT process of the } \\
\text { Portuguese bicycle industry during the } \\
\text { pandemic COVID-19 }\end{array}$ & $\begin{array}{l}\text { São Martinho, B et } \\
\text { all. (2021). [14] }\end{array}$ \\
\hline 9 & $\begin{array}{l}\text { Comparative } \\
\text { Study }\end{array}$ & Competition analysis in the bicycle market. & $\begin{array}{l}\text { Venu, U. S. et all. } \\
\text { (2018). [15] }\end{array}$ \\
\hline 10 & $\begin{array}{l}\text { logistics } \\
\text { management } \\
\text { strategies }\end{array}$ & Factors of global bicycle logistics management. & $\begin{array}{l}\text { Chang, C. H. (2009). } \\
{[16]}\end{array}$ \\
\hline
\end{tabular}

3. OBJECTIVES :

(1) Gaining knowledge on how India's Bicycle industry works. Brief history on India's Bicycle industry is been concentrated here.

(2) To learn about the cycle industry's development in India. The production rate of Bicycle's in India is been monitored and its growth is been recorded.

(3) To study cycles sales/production data in India. Comparative analysis against sales vs productions is been conducted. 
(4) To study the future growth and analysis of the bicycle industry in India. With the help of survey's, the future market analysis of the bicycle industry is predicted.

(5) To learn the contribution of the bicycle industry in international economic development.

(6) To study the research and development in the bicycle industry in India. The research on how new technologies and gadgets could be added.

(7) To know about how Corona impacted India's cycle industry. Measures taken by Bicycle industry during the COVID-19 crisis towards its employees and society to makes their life's better.

(8) To use SWOT Analysis for the recommendation of Bicycle industry future strategies for accelerated success.

\section{METHODOLOGY :}

The data required for this is collected through the journal, published papers, archived newspaper articles, official bicycle industry websites, and other ventures.

\section{THE GROWTH OF THE BICYCLE INDUSTRY IN INDIA :}

India is the second-largest manufacturer in the world and third-largest exporter. From 1978 to 1991, India was the fourth-largest producer of bicycles, behind China, the United States, and Japan. In 1992, it outsmarted the United States and Japan to become the world's second-largest bicycle manufacturer [17].

Table 2: Production of the bicycle in India.

\begin{tabular}{|c|c|}
\hline Year & Production (in Lakh) \\
\hline $1950-51$ & 0.99 \\
\hline $1960-61$ & 10.71 \\
\hline $1970-71$ & 20.42 \\
\hline $1980-81$ & 44.89 \\
\hline $1990-91$ & 61.63 \\
\hline $2000-01$ & 140 \\
\hline $2020-21$ & 200 \\
\hline
\end{tabular}

Based on the above table cycle production in India increases every year [18].

\section{Bicycle Production in India}

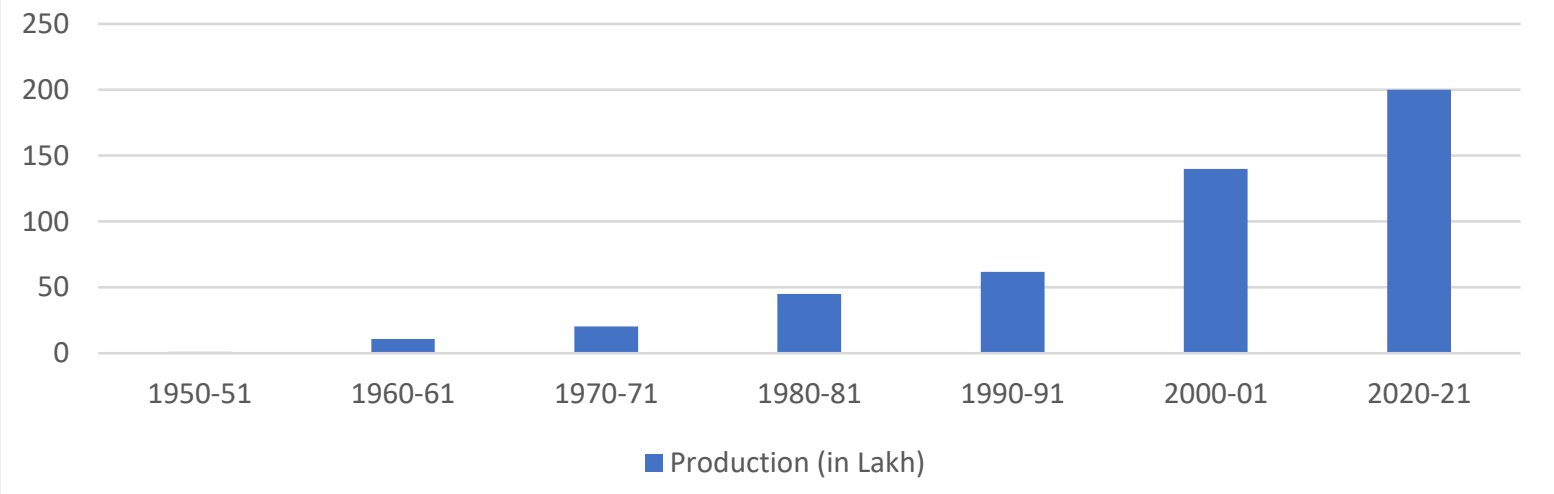

Fig. 1: Chart shows the Production of the bicycle in India

There are two types of bicycles on the Indian market: "standards" and "specials." The rural economy are standards, these low-cost, tough bicycles have remained unchanged for decades. The specials or "fancy" category includes higher-priced new-generation bicycles.

Standards Bicycle: In the early 1990s, Standards accounted for more than $90 \%$ of the market; now, they account for just 66 percent of all bike sales in India. This is due to the fact that a new category of bicycles known as Juveniles, which are classified as specials, has surpassed the standards.

Juvenile Bicycle: The Juvenile, essentially a "standard" bicycle with a more urban appearance, is aimed at young people in semi-urban and rural areas in India. Its popularity can be measured by the fact that, 
between 1996-97 and 2001-02, "Standard "bicycles grew at a 2.7 percent compound annual growth rate (CAGR), while juvenile bicycles grew at a 12.6 percent CAGR. Manufacturers have also been gradually attempting to wean consumers away from the "standard" segment by - marketing efforts and attractively pricing specials.

Kids Segment: Bicycles for children account for 6.4 percent of the overall market share. According to Fig1, the proportion of people buying standardized bicycles has decreased from 90 percent to 50 percent in the last ten years. The kid's segment is a rapidly growing segment of the consumer market. This is good news for cyclist manufacturers because the price range is much more affordable and there is more room for creativity.

The bicycles available from China are mainly for children, with sizes ranging from 12 to 18 inches. These bikes have appealing styles as well as useful features. Indian firms, for example, have only recently adopted battery-powered cycles, while Chinese firms had done so much earlier [19].

\subsection{Types of Bicycles in India:}

City Bicycle: City bicycles are designed for optimum comfort while riding.

Hybrid Bicycles: A hybrid bicycle is a general-purpose bicycle that combines road and mountain bike characteristics for cycling on mixed terrain.

Road Bicycle: Bicycles for the road are designed to operate on mostly well-paved roads. They are the lightest bicycles on the market.

Mountain Bicycle (MTB's): Bicycle through the forests or over sandy or rocky trails in the desert. Mountain bikes are designed for riding in more challenging environments.

Kids Bicycle: Kids' bicycles are basic bicycles with modifications based on the child's age or height. Specialty Bicycles These bicycles are known as specialty bicycles because they are designed for a particular form of cycling.

- Fat Boy Bicycle- As the name implies, these bicycles are fat, and the tires are oversized. They're built for sand, dirt tracks, and rocky terrains.

- Time Trail Bicycle -Its racing bicycle designed for use in an individual race against the clock

- BMX Bicycle- One of the most popular children's bike categories is BMX

- Folding Bicycle - a bicycle that folds up into a small package for easy transportation and storage.

\section{FUTURE ANALYSIS OF BICYCLE INDUSTRY IN INDIA :}

According to research done by market research future, the bicycle global market is going to hit $63474.2 \$$ million between 2018 to 2030 [20]. due to the COVID-19 crisis gone move towards bicycles due to health issues which will attract huge consumers According to research done by Grand View research, the global market size is valued at 54.44 used according to the survey in 2020. this survey says that the growth in traffic will leads consumers to divert to electric bicycles which are cost friendly. According to research done by PERSISTENCE market research, the bicycle industry producing hybrid bikes, for the comfort and attract consumers towards them, it also highlights the point of traffic jam. nearly $24 \%$ growth can be found in the bicycle industry in 2019 According to research done by Intrados global news wire, the global bicycle market has been grown by $5.02 \%$. this survey says that attractive features will attract new consumers globally. nowadays everyone wants a healthy lifestyle. According to research done by Order intelligence, this survey is predicting that the market will boost over 50\% in 2025. due to corona, many new consumers have been added to the bicycle industry. The bicycle industry has a great scope in the future [21]. 


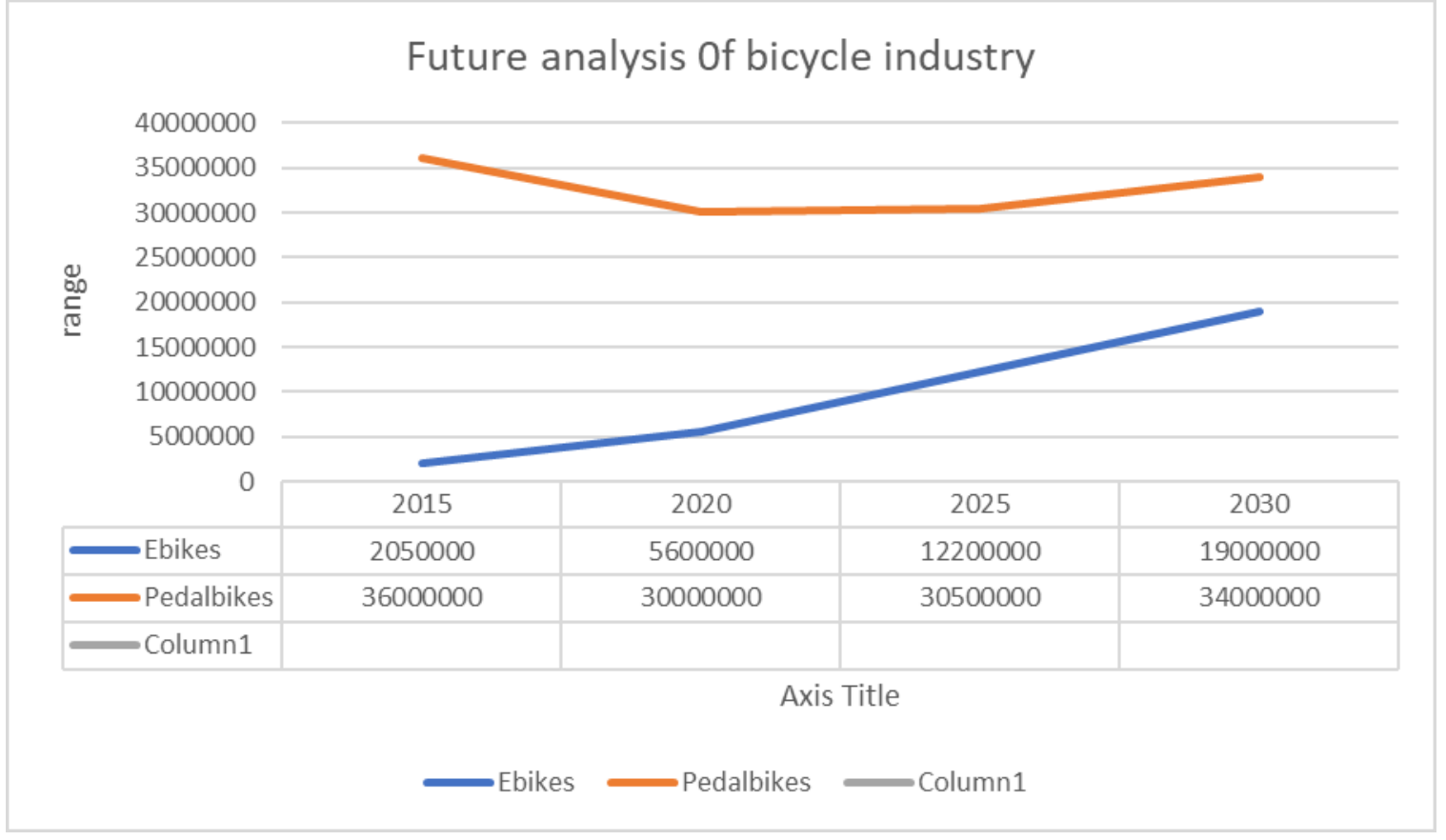

Fig. 2: Chart to show the Future analysis of the Bicycle industry.

Every year, the Indian bicycle industry produces 1.25 million bikes, with new designs, colors, and features appearing virtually every day. Even though environmentalists and the health-conscious express concern about the increasing number of motorized cars on our roads, practically every Indian home still pedal a two-wheeled vehicle.

Trends and Developments in the Market:

- Growing Demand for High-End Bicycles.

- The Demand for Disc Brakes in Sports Bicycles is Growing.

- Increasing bicycle sales through the e-commerce channel.

- Tubeless Tires are Becoming More Popular in Bicycles.

- India's demand for geared bicycles is increasing [22].

\section{MAJOR COMPETITOR :}

The domestic bicycle market is oligopolistic, with three major players: Hero Cycles Limited (Hero), Tube Investments of India Limited (TI), and Atlas Cycles (Haryana) Limited (Atlas). Over $90 \%$ of all bicycle sales in the United States are made by gamers. Avon Cycles and Hamilton are examples of fringe gamers. While TI is the clear market leader in the specialties area, Hero, the world's largest bicycle manufacturer, is the clear market leader in the criteria and the usual home marketplace. Because TI has the largest presence in specialties, and because this department has seen the fastest growth in recent years, TI's volumes have increased the most. Despite having a large foundation of well-known bicycles, Hero has achieved a steady, if slow, increase in specialized volumes due to its strong recognition. Atlas is the most powerful of the three majors, depending on your needs. As a result, its volumes have been subjected to the most extreme stress within the cutting-edge environment [23].

Top organizations inside the enterprise: A huge variety of Indian cycle manufacture layouts for kids, women, women with the listing of functions and add-ons. Here is the listing of exceptional bicycle manufacturers to be had in India, make in India, and discover the closing vacation spot for the USA [22].

- Hero bicycles: Based out of Punjab, it no longer simplest exports to greater than 70 international location show ever have additionally been lively in India with a couple of fashions for 6many years now. Known famously as the 'Cycle of Life', it will now no longer permit you to down. Hero Cycles, on the other hand, is now one of the world's largest bicycle manufacturers, producing 19,000 cycles every day. 
- Atlas: The agency stimulated unending zeal and has the ability to fabricate four billion bicycles a year. ShriJanki Das Kapur commenced the enterprise and made it India's biggest car producer in 1965.

- Avon: The agency roped in Tiger Shroff for its campaigns and has been generating first-class bicycles given that 1948. The Pahwaown circle of relatives commenced the agency for cheap mobility to the not unusual place guy and have now no longer failed the USA in accomplishing the dream.

- Hercules: Resounding the logic with the Greek superhero, Hercules's cycles are made for protection and difficult battles. It is part of the Murugappa institution and has high-quality customer-pleasant shops across the USA.

- La-sovereign: This one is a Thailand logo that has been buying and selling in international markets for forty years now. It works in the direction of anti-pollution, innovation, and modernday designing for clients.

- BSA Ladybird: If you're seeking out a clever but lovable bicycle for your lady, that is the logo you could rely upon. It is part of the BSA shops and offers the precise first-class that a lady need.

- Firefox: With shipping to maximum components of the USA, this logo offers exceptional addons and technician assistance to any customer. Their 'Everyday Ability' marketing campaign is a heartfelt and critical social initiative.

- 8.Montra: The agency believes in driving bicycles first, providing a couple of fashions, assurance, and extra motor-cycle add-ons as and while its miles required.

- Mach City: With the dream of permitting clients to 'rediscover cycling', Mach City motorcycles are revolutionary and agile. Be it for a brief distance trip or a city-huge own circle of relatives excursion on cycles, Mach city wins.

- Road Master: This agency is enormous throughout the nation, with greater than 156 shops. They have franchise alternatives however constantly offer assurance and progressive coloration alternatives to users.

Table 3: Best cycle brands in India and World [24]

\begin{tabular}{|l|l|l|}
\hline $\begin{array}{l}\text { Best cycle brands in } \\
\text { India }\end{array}$ & Year & Customer Rate \\
\hline Avon & 1951 & 4.1 \\
\hline BSA & 1964 & 4.2 \\
\hline Firefox & 2005 & 4.1 \\
\hline Hero & 1956 & 4.1 \\
\hline Mach city & 2016 & 4.1 \\
\hline Omo Bikes & 2016 & 4.5 \\
\hline Fitrip & 1985 & 4.2 \\
\hline Kross & 2012 & 3.8 \\
\hline
\end{tabular}

Table 3 shows the average rate given by the customer in all brands of the bicycle

\section{CONTRIBUTION OF BICYCLE INDUSTRY IN INTERNATIONAL ECONOMIC DEVELOPMENT :}

The significant surge in global demand for bicycles is as much or more a function and symptom of the tremendous economic development that has occurred around the world since 1970, rather than an Eco Indicator of environmental conservation efforts. Bicycles become affordable to much wider segments of the population of developing countries much before cars do, at a fraction of the cost of cars. The sharp rise and divergence in bicycle and car production coincide with a particularly productive period in global economic development. Between 1970 and 2009, the average gain in the Human Development Index (HDI), which closely correlates with per capita income levels, was a healthy 44 percent for countries all over the world [25].

Table 4: Bicycle production of selected countries, in millions

\begin{tabular}{|l|l|l|l|l|}
\hline Country & $\mathbf{1 9 8 5}$ & $\mathbf{1 9 9 0}$ & $\mathbf{1 9 9 5}$ & $\mathbf{2 0 0 0}$ \\
\hline India & 5.3 & 8.4 & 11.5 & 11.0 \\
\hline
\end{tabular}




\begin{tabular}{|l|l|l|l|l|}
\hline China & 41.0 & 31.9 & 41.0 & 52.2 \\
\hline Germany & 2.9 & 3.9 & 2.9 & 3.2 \\
\hline Italy & 1.6 & 3.5 & 5.3 & 3.2 \\
\hline Japan & 7.8 & 8.0 & 6.6 & 4.7 \\
\hline Taiwan & 9.9 & 6.8 & 9.7 & 7.5 \\
\hline United-Kingdom & 1.2 & 1.3 & 1.2 & 1.2 \\
\hline United-State & 5.8 & 5.6 & 2.5 & 1.1 \\
\hline
\end{tabular}

Table 4 shows China alone accounts for a substantial portion of the global bicycle market's growth, so China becomes a "Global Bike Capital". China's rapid economic growth supports higher market penetration rates for Chinese manufacturers, and rising per capita incomes provide up-and-coming Chinese with the means and motivation to replace old bicycles with better, new models. A strong rise in the world market for so-called e-bikes has been one effect of Chinese people's advances up the economic ladder and bicycle food chain.

\section{THE RESEARCH AND DEVELOPMENT CENTRE FOR BICYCLE IN INDIA :}

The Punjab Government established the Research Development Center in 1983 with UNDP/UNIDO funding with the goal of assisting the industry in adopting novel technology to boost productivity and product quality. It was outfitted with cutting-edge machinery for manufacturing, testing, calibration, and training. The center's key goals are as follows: [26]

1. Establish and maintain facilities for expanding and diversifying output.

2. Ensure that the production center's productivity is at its peak.

3. Improve quality to meet international standards

4. Provide job-specific and professional training

The Research Development Center provides marketing and advising, product design and development, a precision tool room, testing and calibration, special-purpose machine building, mass-production machinery, and essential training to the industry. The center's focus is on SMEs in the cycling sector that requires technical support and a single location for some of these services.

\section{SWOT ANALYSIS :}

SWOT Analysis is used to determine the various internal and external factors that will directly affect their operations or business. Every industry maintains a visible position in the IT sector by carefully examining and auditing their SWOT to improve efficiency [27]. SWOT-analysis helps to exploit chances with thought [28]

Strengths: The Indian bicycle industry is virtually unable, with domestic sources responsible for more than 95 percent of bicycle parts. It also imports the majority of its raw materials from within the nation, such as steel tubes [29].

- Its emphasis on developing a simple, low-cost, and somewhat outmoded car may be interpreted as an intentional attempt to address the fundamental mobility demands of the less wealthy populace. The industry has the potential to manufacture a low-cost roadster platform.

- It has not adopted any foreign technology, instead of creating or modifying the majority of the technology it uses and focusing on labor-intensive production procedures.

- The final product is extremely concentrated since it sources a considerable amount of its components from a huge number of small businesses.

- All most $90 \%$ of its exports go to other developing nations, where many of the less wealthy populations' basic transportation requirements go unmet.

- In several developing countries, India has been wildly successful in establishing collaborations and contracts for the manufacturing of bicycles and components. This development could be due to India's ability to provide technology that satisfies the demands of many developing countries.

- The replacement market alone to estimate to generate sales of 3 million bicycles in the not-toodistant future. 
- Because cost contributes for 80 percent to 90 percent of competitiveness in the low-end market, where customers are searching for consistent quality at a reasonable price, low labor costs and long-term quality/price consistency are crucial.

- Ludhiana's concentration of industry enables it to benefit from collective productivity resulting from a pool of available expertise, specialist suppliers and attracting customers, as well as cooperative action to conduct collective facilities such as customs clearance.

- The presence of a large number of vendors in one location has aided in the development of lowcost infrastructure and just-in-time deliveries.

- Small firms in the bicycle parts industry have mastered the art of producing a large number of components that are both durable and strong for OEM and replacement markets.

- The industry has created a framework that is built on the usage of dependable and simple technologies. The tight integration of large component suppliers has ensured that every ounce of basic raw material, such as steel, is used waste generated in one process becomes an input for another. This has resulted in increased pricing utilization as well as waste reduction.

- The Indian cycling production has attained a certain degree of product quality within competition constraints, making imports of similar Chinese or other foreign-made goods currently uneconomical. Over all the decades, a vast network of deals/sub dealers has been developed. These distributors connect the bicycles, allowing businesses to send bike units in CKD format and save money. Such a setup is hard to emulate, and despite the success of Branded products and the lack of a very well international bicycle product in the price range, it acts as a significant entry barrio for imported goods from other reduced countries like China. It would be impossible for any elite player to balance the supply of spare parts in the world at very competitive rates.

\section{Weakness:}

- The Indian bicycle market is just about $1 \%$ of the global market, thanks to low-cost, low-quality goods. It is essential to strengthening the vendor base, and even the critical infrastructure and resolve logistical problems, to produce higher-end bicycles for the global and domestic markets.

- Even so, the Indian bicycle industry acknowledges that the value of its products must be increased unable to thrive in international markets. Technology and quality improvements must be built into any aspect and facet of the bicycle. In this sense, possibilities for international cooperation exist, but mostly for the manufacture of specific types of parts.

- Entrepreneurs' simple mechanical skills are best geared to copying/adapting rather than developing new inventions. Via creative R\&D activities, there is a need to provide technical assistance in the context of evolving and rendering accessible superior technology.

- India has fallen behind other mature economies that are the optimum business of bicycles and parts, due to a lack of modern product production and the use of stronger and lighter metals such as aluminum alloy [30].

Opportunity: Opportunities can arise as a result of a variety of reasons, including rising consumer income, economic growth, political issues, and government policy changes, new technology, and customer views.

- Expanding Market Size and Changing Consumer Preferences - The market has risen at a rapid pace during the previous decade and a half. Consumer preferences, views and tastes have evolved because of the entry of new clients.

- Increase in Consumer Disposable Income - Bicycle can take advantage of rising disposable income to create a new business model in which customers pay progressively for their use of the company's products.

- Artificial Intelligence Advancements - Bicycle can leverage artificial intelligence (AI) advancements to better predict consumer demand, cater to niche segments, and improve recommendation engines.

- Changing Technology Landscape - Machine learning and Artificial Intelligence may be used to improve efficiencies, cut costs, and revolutionize processes. 


\section{Threats identified:}

- US-China Trade Relations - focusing on China's next stage of development. However, there is a growing strain in US-China economic ties, which might lead to protectionism, more friction in international commerce, and higher labor and corporate expenses.

- Government Laws and Bureaucracy - Industry should keep a close eye on the rapidly changing government regulations because of increasing pressure from protest groups and nongovernmental organizations, particularly in the areas of environmental and labor safety.

- Industry culture of sticky prices - Bicycle operates in an industry where sticky prices are the norm. It may result in the organization's inability to raise prices to the level that its premium rates demand.

- Squeezing the Middle Class in the Developing Worlds - Growing inequality is one of the most serious risks to globalization and capitalism.

- Growing Protectionism - Industry can take actions to reduce the danger of increased protectionism, such as keeping data in foreign markets and diversifying risk by doing business in countries with different economic cycles.

- Buyers' bargaining power is growing - Bicycle customers' bargaining power has grown dramatically over the years, putting downward pressure on pricing. To consolidate and gain efficiencies, the company can pursue horizontal integration [31].

\section{CSR ACTIVITIES :}

Corporations are residents of the cities in which they reside, and their workers are members of the societies in which they serve. Corporate responsibility and the expectation of facilities and systems from the city administration will all contribute to a safe and healthy atmosphere. Employee fitness and wellbeing are dependent on physical exercise and a safe, stress-free drive to and from work, among other success and incentive schemes that corporations run from time to time. In these days of extreme traffic congestion in Indian cities and around the world, taking public transportation or cycling to work is a form of Corporate Social Responsibility! - and will have a significant effect on citizens' everyday lives [32].

Here are a few steps that corporations should do to help achieve this goal:

a) Be the Messenger! - Organizations' HR divisions will help spread the idea of environmental protection while also promoting a healthier workforce by encouraging employees to cycle, bike, or use public transportation to work. Promote and organize activities and workshops to raise awareness, answer questions, and alleviate concerns.

b) Honored, Privy Parking! - Reward workers who ride their bikes to work with privileged parking spaces that are readily available and clear, near to their workplaces and elevators! Others will be held liable for the high-priced real estate and parking spaces they use in the workplace!

c) Cycling Allowance! - Workers who ride their bicycles to work save businesses a lot of money on parking real estate because bicycles only need a small amount of room to park.

d) Showers in the Office! - will go a long way toward inspiring workers to bike to work and shower before starting work, just as they would after a gym visit. Good sweat and toil must be encouraged!

e) Outings and Off-sites on cycles - Encourage project teams and administrators to incorporate cycling into their next team bonding events and offsite sessions.

\section{COVID-19 IMPACT ON "INDIAN BICYCLE INDUSTRY" :}

Like many other countries around the world, India has imposed a national lockdown. During the lockdown time in India, all social gatherings, such as bicycle races, are banned. Bicycle demand is expected to decline in 2020-21 as a result of the nationwide lockdown. COVID-19 is a challenge for market growth due to all these factors. Covid-19 has impacted the industry mostly in terms of revenue, as April, May, and June are considered the best months for sales. Since so much money is spent in the industry, the pandemic has disrupted the entire supply chain. The situation has deteriorated due to a labor shortage. The lockdown has driven the entire supply chain into chaos. Migrant laborers make up most of the workforce. So, right now, that is an issue. However, after the lockdown has ended, they will 
be able to work back with the tools that are available [33]. Expressing optimism believes that the growing concern for environmental issues works out well for the cycle industry. Fearing COVID-19 infection in crowded areas, fitness enthusiasts are now opting to cycle to go to gyms. The pandemic has benefited the bicycle industry. Air pollution is a source of concern. People and the government are becoming more aware of Mother Earth's protection as a result of environmental improvements seen during the lockdown. Since the cycle does not pollute the climate, it has a "prosperous future."

In addition, Prime Minister Narendra Modi's slogan, "Vocal for Local," gives Indian manufacturers an advantage [34]. However, due to a labor shortage and delays in importing special gear from overseas markets, the cycling industry is unable to meet demand.

\section{RECOMMENDATIONS :}

We recommend the following enhancement suggestions based on the aforementioned analysis: To produce and sell exportable bicycles and components for the industry-wide transition, it is most recommended that the aforementioned barriers should overcome these inventions such as:

- The Government should develop good infrastructure for the development of the cycle industry, keeping in mind the health of people, the environment, and fossil fuel saving.

- Traditional skills and knowledge, as well as the introduction of new technology, financing, and marketing tactics, can help to sustain and strengthen this industry.

- The State government must provide interest-free loans to the small manufacturers to help them execute orders. People should also be made aware regarding bicycle usage. To facilitate the economical supplies of these requirements of raw materials to these manufacturers the establishment of material banks is necessary.

- Providing components to the manufacturers- for efficient and competitive production manufacturing the SMEs and technical guidance and the handholding through a variety of modalities is required. These can include the deployment of technical experts for the handholding service, sharing technology mechanisms, and co-developing the technologies for demonstrating, focus test supports, and testing quality services.

- The international sales and marketing have an establishment of a common node or entity, such that very common brands for the numerous, unrecognized brand of component-manufacturing Indian SMEs. The appropriate policy advocacy efforts can be added for the support of the main needs of the industry.

- Companies must concentrate on the application of artificial intelligence (AI) in the design of paddle cycles to automate speed control and anti-theft measures.

\section{CONCLUSION :}

The Indian bicycle has been facing several challenges in achieving export competitiveness. The industry mainly produces large models of steel roadster bicycles, children's bicycles, and a small, limited volume of premium bicycles. The bicycles which were demanded in the global markets are aesthetically and technically more superior than those produced domestically, which are created from high-end materials, are of multiple speed setting and they require many special components which are often from the specific brands and even through the second-largest bicycle industry in the world is Indian bicycle industry in terms of volume, manufacturers have been facing several demand and supply related barriers when producing bicycles which are demanded globally which is explained in the course of this report. They include the raw materials that have a lack of access to appropriate grades and forms at affordable prices mainly including aluminum alloy. To gain access to international markets and consumer confidence there is a need for international marketing and selling channel.

\section{REFERENCES :}

[1] Introductions on Bicycle retrieved from https://www.choosemybicycle.com/en/ on 1/7/2021.

[2] Bicycle Industry Report retrieved from https://www.goldsteinresearch.com/report/india-bicycleindustry-analysis on 1/7/2021.

[3] Gupta, S, Mehta, Y. (2020). process redesign and information technology impact on product quality in bicycle industry: assessment through business process reengineering. International Journal of Management (ijm), 11(11), 1816-1824. 
[4] Munjal, (2020). a bicycle built for two: tracing India's post-independence economic growth. international journal of social science and economic research, 5(11), 3660-3668.

[5] Sambit Kumar Beura, Haritha Chellapilla, Mahabir Panda, Prasanta Kumar Bhuyan, (2021). Bicycle Comfort Level Rating (BCLR) model for urban street segments in mid-sized cities of India. Journal of Transport \& Health, 20(1), 1-10.

[6] Samyajit Basu, Vinod Vasudevan, (2013). Effect of Bicycle Friendly Roadway Infrastructure on Bicycling Activities in Urban India. Procedia - Social and Behavioral Sciences, 104(1), 11391148.

[7] Glen Norcliffe, (2016). The bicycle: towards a global history. Studies in Travel Writing, 20(3), 313316.

[8] Amit Agarwal, (2021). Quantifying Health \& Economic Benefits of Bicycle Superhighway: Evidence from Patna, Procedia Computer Science, 184(1), 692-697.

[9] Dhanyashree, G., Vijayasree, M., Kumar, H. S., Dinesh, V., \& Lakshmipathy. N, (2021). Design of Electric Powered Bicycle. International Journal of Engineering Research \& Technology (IJERT), 1(1), 1-7.

[10] Nath, S., Sinha, S., Gladence, L. M., BevishJinila, Y. and Rajalakshmi, V. (2017). Health analysis of bicycle rider and security of bicycle using IoT. International Conference on Communication and Signal Processing (ICCSP), 1(1), 802-806.

[11] Tabei, F., Askarian, B., and Chong, J. W. (2021). Accident Detection System for Bicycle Riders. IEEE Sensors, 21(2), 878-885.

[12] Valiachi, G., (2020). Export Performance of Bicycle and Parts in India: An Econometric View. Shodh sarita- an international multidisciplinary quarterly bilingual peer reviewed refereed research journal, 7(28), 151-156.

[13] Baviskar, D., Bhosale, A., Baswa, A., \& Kulkarni, K. (2021). Review on various design aspects of the modern bicycle. In IOP Conference Series: Materials Science and Engineering, 1136(1), 1-9.

[14] São Martinho, B., Azevedo, A., \& Malta, M. (2021). Covid-19 as the trigger for digital transformation: The case of the bicycle industry in Portugal. Research Bulletin (Cadernos De Investigação) of the Master in E-Business, 1(1), 1-11.

[15] Venu, U. S., Singh, V. K., \& Aryasri, A. R. (2018). Buying Behaviour of Bicycle Customers in India: A Comparative Study of Hero Cycles and B-Twin. Journal of Marketing Vistas, 8(2), 13 27.

[16] Chang, C. H. (2009). A study of global logistics management strategies: based on the bicycle manufacturing. Journal of Statistics and Management Systems, 12(3), 543-559.

[17] The growth of the bicycle retrieved from https://www.freepressjournal.in/lifestyle/bicycle-diaries on $11 / 7 / 2021$.

[18] Production of the bicycle in India retrieved from https://www.google.com/search?q=Chart+shows+the+Production+of+the+bicycle+in+India\&tb $\mathrm{m}=$ isch\&source=iu\&ict $=1 \&$ fir $=\mathrm{I} 62 \mathrm{PH}-\mathrm{ol} 3 \mathrm{kqZ} 3 \mathrm{M} \% 252 \mathrm{Cp} 1$ -

E8pjlYZfb3M\%252C \&vet=1\&usg=AI4 -

kR8h3TNzIRBkVd43MPb4u9jPWQ\&sa=X\&ved=2ahUKEwj0m4icnPHxAhXIb30KHQzTCosQ 9QF6BagMEAE\#imgrc=0F375ZD0gwE5TM on 12/7/2021.

[19] Types of Bicycle retrieved from https://www.edinburghbicycle.com/blog/types-of-bikes-buyingguide on $15 / 7 / 2021$

[20] Global marketing strategies retrieved fromhttps://www.grandviewresearch.com/industryanalysis/bicycle-market on 15/7/2021.

[21] Valiachi, Ganesh (2020). Export Performance of Bicycle and Parts in India: An Econometric View. Shodh sarita - journal of arts, humanities and social sciences, 7(28), 151-156. 
[22] Market trend retrieved from https://www.prnewswire.com/news-releases/india-bicycle-marketcompetition-forecast-and-opportunities-2021-increasing-demand-for-disc-brakes-in-sportsbicycles---research-and-markets-300455231.html on 16/7/2021.

[23] Competitor analysis retrieved fromhttps://www.marketingmind.in/top-10-brands-bicycle-brandsin-india-2020/ on 16/7/2021.

[24] Bicycle brand retrieved from https://www.velocrushindia.com/best-cycle-brands-india/ on $\underline{17 / 7 / 2021 .}$

[25] International economic development retrieved from https://www.mbarendezvous.com/casestudies/cyclecasestudy/ on 17/7/2021.

[26] Research on Bicycle retrieved from https://www.unido.org/sites/default/files/files/202002/Bicycle\%20-\%20Industry\%20assessment\%20report.PDF on 18/7/2021.

[27] Prabhu, Sangeetha, \& Bhat, Subrahmanya, (2020). Application of Artificial Intelligence in Samsung - A Case Study. International Journal of Case Studies in Business, IT, and Education (IJCSBE), 4(2), 280-292.

[28] Aithal, P. S., and Kumar, P. M. (2015). Applying SWOC Analysis to an Institution of Higher Education. International Journal of Management, IT and Engineering, 5(7), 231-247.

[29] SWOT analysis retrieved from https://tabatorium.com/mzqgca/bicycle-swot-analysis on $18 / 7 / 2021$.

[30] Weakness of the industry retrieved from https://www.expertmarketresearch.com/reports/bicyclemarket on 18/7/2021.

[31] Opportunities and threats are retrieved from https://embapro.com/frontpage/swotcase/16032-bikeca on 19/7/2021.

[32] CSR activity Retrieved from https://yulubike.wordpress.com/2018/04/26/corporate-support-forcycling-corporatessupportcyclingtowork/ on 19/7/2021.

[33] Effect of Covid retrieved from https://www.tribuneindia.com/news/ludhiana/pandemic-to-benefitbicycle-industry-98796 on 19/7/2021.

[34] Effect of COVID-19 retrieved from https://www.news18.com/news/buzz/indias-bicycle-craze-isbrought-in-by-the-coronavirus-pandemic-whats-next-in-2021-3380285.html on 20/7/2021. 